

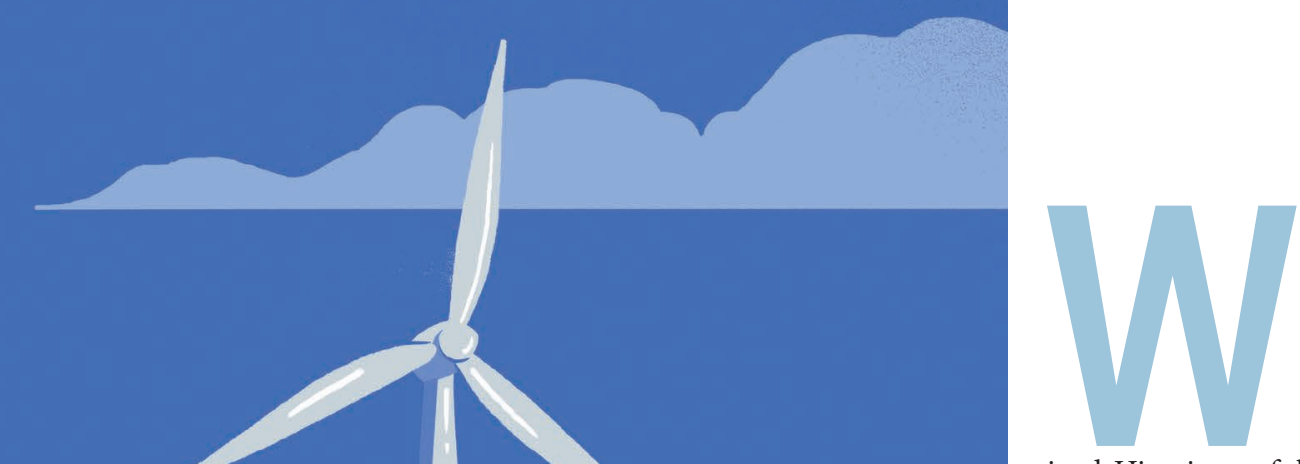

BY STEPHANIE PAIN ined. His seizure of church property delivered the coal-rich lands of northern England to profit-minded people who turned small-scale extraction into a flourishing industry. Over the next two centuries, coal replaced wood as the country's main source of energy, fuelling the expansion of industry and of the urban population. "The shift from wood to coal was arguably the most momentous in the history of energy," says Roger Fouquet, an energy researcher at the London School of Economics and Political Science. "The impact on society was huge."

The story of human progress - from nomadic hunter-gatherer to smartphone-wielding urbanite - is the story of energy (see 'A high-speed history of energy'). Harnessing alternative sources of energy led to a proliferation of technologies that provided better heating, lighting, power and transport, and ultimately led to the high-energy world of today. Changes have generally been slow, driven sometimes by supply, sometimes by demand - and occasionally by random events such as a king's fancy for a new wife. "Each case is different," says Fouquet. "In some cases, new sources of energy came to be dominant. In others, they were more of a stopgap with just a cameo role in the history of energy."

As society embarks on the next momentous energy shift, the past offers important lessons. "It's vital that we make the transition from the current global energy system, which relies overwhelmingly on fossil fuels," says Benjamin Sovacool, an energy-policy researcher at the University of Sussex in Brighton, UK. "With knowledge from past transitions, we can accelerate the process and shape a different future."

\section{BURNING AMBITION}

For most of human history, people relied on their own musclepower, fuelled by food, while fire provided heat and light. Even as agriculture emerged, followed by towns and cities, human muscles - and those of domesticated animals - were still the main source of power. Innovative tools and technology made their effort go further: properly controlled, fire could transform clay into pots and bricks, and smelt metals to be worked into tools.

By the third century вС, people were exploiting a more powerful source of energy: water. The ancient Greeks used simple water mills to drive grindstones. In the first century $\mathrm{AD}$, Chinese iron workers were firing up their furnaces with water-powered bellows. By the end of the eleventh century, water power was being used across Western Europe to mill grain, process cloth, tan leather, saw wood and crush ore. The extra power boosted productivity: one mill and a handful of people could grind enough flour to feed a town, freeing others to develop a wider range of trades. The cost of producing flour and bread fell. For many, quality of life began to improve. With water mills, however, "the people who owned water rights controlled the energy supply", says Arnulf Grubler, a researcher at the International Institute for Applied Systems Analysis in Laxenburg, 
Austria. Windmills were first seen in seventh-century Persia. When they reached Europe in around 1150, they gave more people access to power, albeit subject to the vagaries of the weather. "Windmills were a more democratic technology," Grubler says.

As medieval Europe's population burgeoned, traditional small-scale industries also grew, setting the scene for the first energy revolution: the switch from wood to coal. For millennia, wherever there were visible, easy-to-dig outcrops of coal, people had exploited them. Ancient China fuelled much of its early industrial activity with coal. But the big change began in England in the sixteenth century, driven largely by the needs of the country's capital - London. The city had imported small amounts of coal from the north of England since the thirteenth century, mostly for use in lime kilns and forges, but its foul smell and black smoke meant that Londoners stuck to wood and charcoal for domestic use. By the sixteenth century, however, England's forests had been overexploited, and the transport of wood over ever longer distances to London made it expensive. With the northern coal-bearing lands wrested from the church, the mining industry grew - and soon fleets of boats were supplying what Londoners called sea coal.

\section{COAL ASCENDANT}

At first, only the poor burned coal, but soon the shortage of wood drove even wealthier residents to adopt it. Technological innovation, such as better designed fireplaces, flues and chimneys, led to wider adoption. Industries, from brewing and soap-making to dyeing and brick-making, joined the lime-burners and blacksmiths in burning coal. Such was its uptake that, by 1661, English diarist John Evelyn compared London to "the suburbs of Hell", shrouded in "clowds of smoake and sulphur, so full of stink and darknesse". One key industry, the iron industry, took longer to make the shift: coal gives off sulfurous compounds that make iron brittle, a problem that wasn't solved until the early eighteenth century with the discovery of a way to smelt iron using coke - coal 'cooked' to produce almost pure carbon.

Coal wrought huge changes in society. "It reduced the pressure on land because energy could be found below ground," says Fouquet. Coal made homes less expensive to heat, and brought down the price of metal goods that required heat to produce. "And because coal was so cheap, inventors found new ways to use heat to produce power, which in turn transformed our lives further."

To meet the growing demand, coal mines sprang up in other regions of Britain. Deeper mines were prone to flooding, so steam engines were developed to power water pumps. Canals were dug to transport coal to the cities. Both were fundamental to the Industrial Revolution that followed. "Advances in engineering, technology and culture all combined to get the Industrial Revolution started," says Fouquet. "But it wouldn't have taken off without coal."

By the 1770s, a new generation of more efficient and less fuel-hungry steam engines was powering a surge in economic growth. Freed from the need to be close to mines, steam engines could be used almost anywhere. That led to the emergence of new industrial centres and bigger factories with more specialized machines. Demand for labour spurred migration from the countryside to the cities. By the end of the century, the canal network - followed a few decades later by the railway — allowed bulk movement of coal, food and manufactured goods.

Although Britain was the first nation to make the transition to coal, it was a slow process. "It was only in the 1800s that it was used in a large way for power and transport," says Fouquet. "By 1880, coal was hugely dominant in all services." Other countries continued to rely on wood until the demands of their burgeoning industries drove them to follow Britain's lead. In Germany and France, which were less densely populated and had extensive forests, wood remained the primary source of

\section{A HIGH-SPEED HISTORY OF ENERGY}
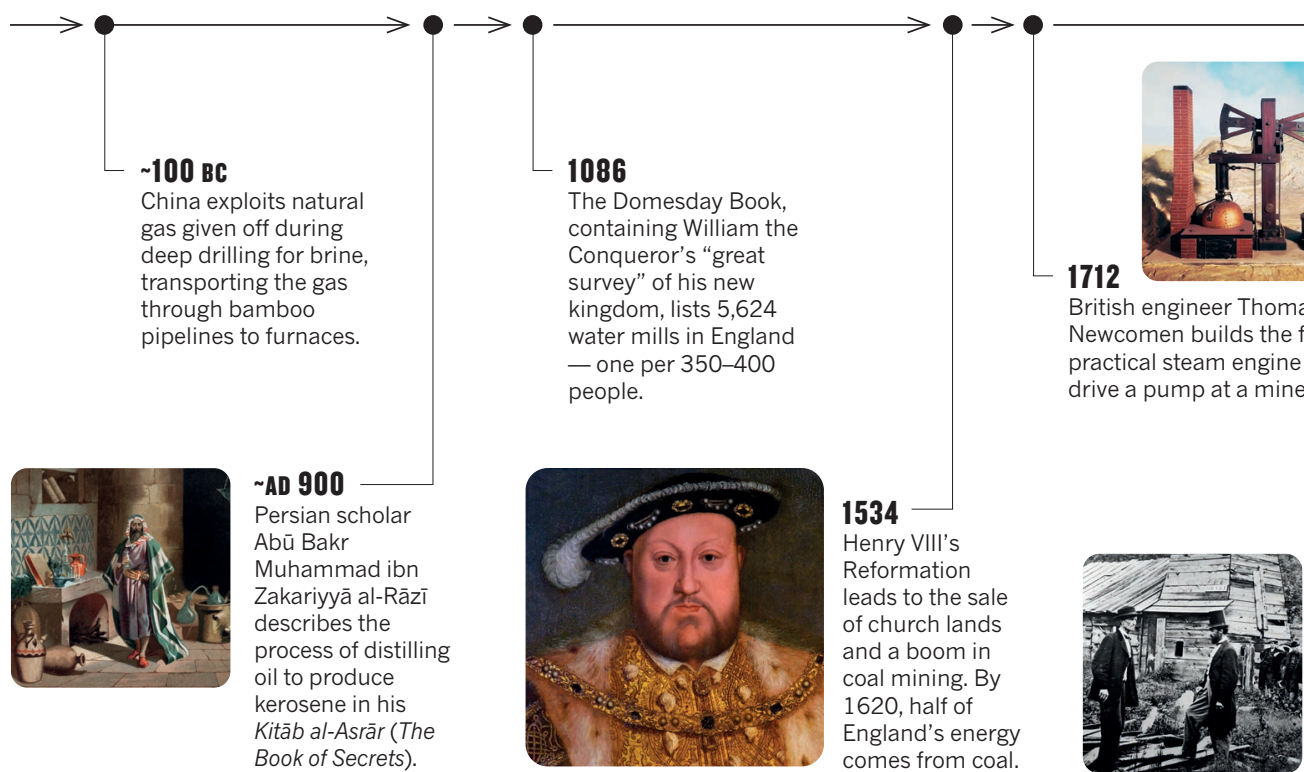
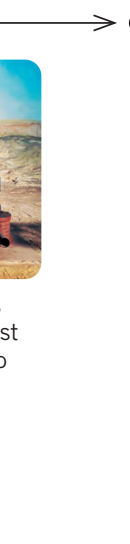

1858-59

Edwin Drake drills the first commercial oil well in Titusville, Pennsylvania. The well is 21 metres deep and produces around 1,500 litres of oil a day.
1882

In London,

Thomas Edison opens the first coal-fired power station, providing electricity for lighting, followed a few months later by Pearl Street power plant in New York City, which has the capacity to light 7,200 lamps. 
energy until the 1850s. In the United States, coal overtook wood only in the 1880 s.

For the industrializing world, the move to coal brought enormous benefits. More people were better off and had access to a wider range of goods. Expanding rail networks and steamships transformed trade and offered ordinary people greater mobility. But there were also drawbacks. "The downside was more crowded, polluted cities, housing misery and problems of clean water supply and sanitation," says Grubler. "But with more money those problems could be overcome - and as economic growth generated more wealth, things improved."

Even as coal was in the ascendancy, new sources of energy began to make their mark. Town gas (derived from coal) became available for lighting and heating in the early nineteenth century, initially in London. But connecting to the gas supply was costly, and its use was limited to urban areas. Gaslights made city streets safer and changed working practices and leisure activities - including sleep patterns. Later that century, paraffin (kerosene) - the first product of the newly exploited Pennsylvania oil fields - provided a cheaper alternative to whale oil for lighting poorer homes and those in rural areas.

\section{WE ARE ELECTRIC}

By the late nineteenth century, another type of power was poised to make its debut: electricity. Coal-fired power stations appeared in Europe and the United States in the 1880s, first for lighting and then to power trams and trains. Industry followed in the first half of the twentieth century. "The electrification of factories made production systems much more flexible and more reliable," says Fouquet. Power now came at the flip of a switch. Working conditions improved: factories were cleaner and safer, and much more productive.

Electrification transformed the home, too: irons, fans and water heaters appeared before 1900, later joined by cookers, fridges, washing machines and all manner of labour-saving devices. "Electricity revolutionized communications, from the telegraph and telephone to the radio, the TV and the Internet," says Grubler. "Thanks to electricity, most of us in developed countries have luxuries even the poshest houses in Victorian times didn't have."
Around this time, oil looked as if it might play only a minor part in the energy story. That changed with the invention of the internal combustion engine and the rise of the cheap, mass-produced motor car. Demand for petroleum soared and, as the oil industry expanded, new uses for oil were found - including generating electricity.

The availability of cheap, reliable electricity was changing the world, but it came at a price. By the mid-twentieth century there were growing concerns about how long fossil-fuel reserves might last. The oilprice shock of 1973, which saw prices quintuple, spurred many nations to look for alternative energy sources and to develop more-efficient technologies. Some countries, such as the United Kingdom, favoured natural gas. Those that could, notably Norway, harnessed hydropower. Others, such as France and the United States, turned to nuclear.

As the century wore on, it became increasingly clear that the world's reliance on fossil fuels posed other dangers. Deteriorating air quality, largely caused by emissions from power stations and vehicle exhausts, is now one of the greatest public health issues. "Power plants, cars and household cookstoves are some of the biggest killers on the planet," says Sovacool. The same emissions are also largely responsible for climate change (see page S145).

Today, there's a fresh revolution under way, driven by the need to satisfy the ever-increasing demand for energy - particularly in developing nations - without worsening the problems created by those who industrialized first. "If we don't make the transition away from our current global energy system soon, it could be too late," says Sovacool.

If the past has taught us anything, it's that we should be able to do things differently this time. "Past transitions were mostly chaotic and unpredictable," says Sovacool. "This time we can actively plan and manage transition." The current energy change is driven not by convenience or by a new discovery, but by society. "People want novel and cleaner services, and these can be provided with much less energy," says Grubler. Consumers, he argues, will drive demand for new technologies and new services, and changes in behaviour and preferences will drive new ways of providing them. "The future," he adds, "could be very different from today." -

Stephanie Pain is a freelance science journalist in Brighton, UK.

\section{4} generates electricity using geothermal energy. In 1911, the world's first geothermal electric power station is built at Larderello - it goes on to supply Italy's railways.
At Larderello in Italy, Piero Ginori Conti

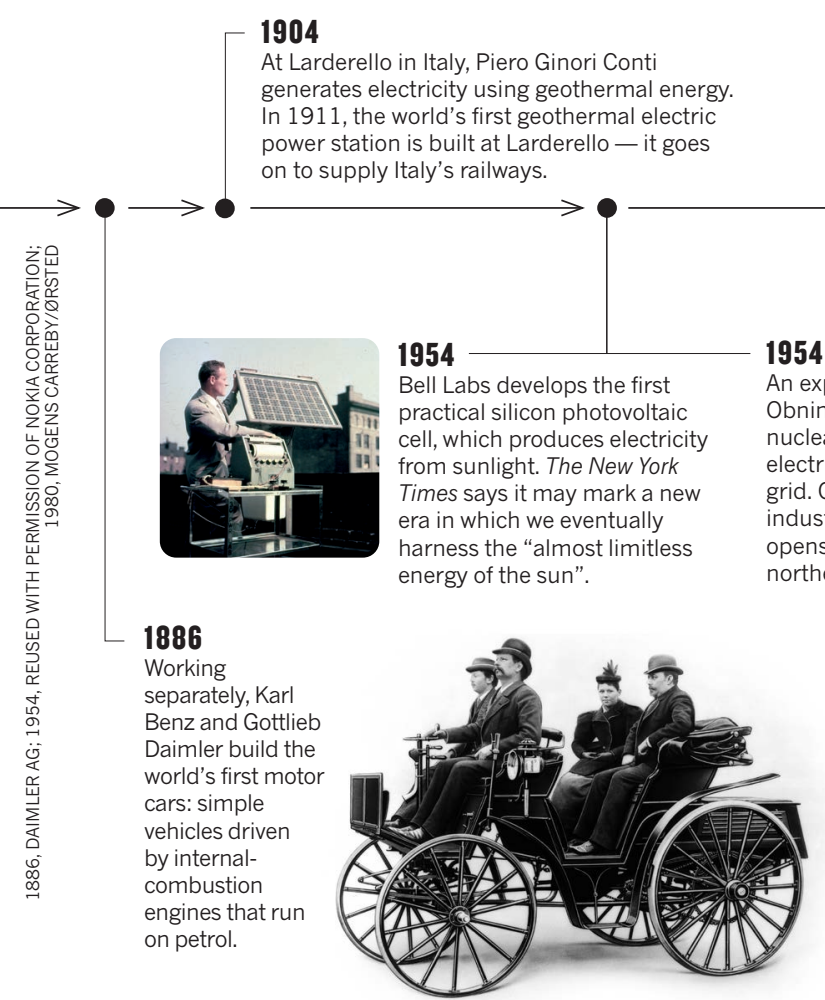

1975

Brazil launches its Pró-Álcool programme to turn sugar cane into ethanol to fuel cars. By $1981,90 \%$ of new vehicles sold in Brazil can run on ethanol.
2009

China's rapid economic growth sees it overtake the United States in energy consumption. By 2015, it used 32\% more than the United States, although its per capita consumption was only one-third as much. 